\title{
Red Deer Population Census in Mountains: Testing of an Alternative Method ${ }^{1}$
}

\author{
Bogusław BOBEK, Kajetan PERZANOWSKI \& Jan ZIELIŃSKI
}

Bobek B., Perzanowski K. \& Zieliński J., 1986: Red deer population census in mountains: testing of an alternative method. Acta theriol., 31, 31: 423-431 [With 2 Tables \& 3 Figs.]

The population numbers of red deer, Cervus elaphus (Linnaeus 1758), in four forest districts in the Bieszczady Mountains were estimated on the basis of social structure and the number of roaring stags according to Langvatn formula. On October 3 both factors reflecting deer activity i.e. the average number of roaring stags heard per hour (4.4) and the average number of deer sighted per hour (7.2) were highest. It was assumed that the peak of rutting activity fell on the period between 2 to 4 October. The average harem size was equal to 3.6 animals with harems of three as the most common size (30\% of all sightings). The deer densities found in the studied areas were: $7.4 ; 6.2 ; 5.4$ and 4.7 per 100 hectares respectively in Stuposiany, Cisna, Komancza and Wetlina districts. These figures obtained at the beginning of hunting season, exceed the official snow tracking estimates made at the end of the winter by 2 to 5 times. In mountaineous hunting grounds the presented method proved to be cost effective and yielded much more reliable estimates than hitherto used method of red deer census.

[Dept. Anim. Ecol., Jagiellonian University, Karasia 6, 30-060 Kraków, Poland].

\section{INTRODUCTION}

A comprehensive management policy planning requires reliable data on population numbers to decide upon harvest quota and to determine recruitment rate. Tracking method still widely used is not suitable for intensive harvest system, because of serious underestimating the true number of animals. In red deer population, the actual population number can even exceed 3 to 4 times the figure obtained by tracking method (Bobek \& Tomek, 1973; Pucek et al., 1975).

Such underestimation of deer stock leads to setting of very low harvest cealings that in turn causes overpopulation and damages like bark stripping or browsing. As early as in the sixties, Polish scientists started working out a handy, quick, inexpensive and effective method for

\footnotetext{
1 Pracę wykonano w ramach problemu MR-II/19 koordynowanego przez SGGW.
} 
the estimation of population density in cervids. Parallel use of drive census to verify estimates of tracking method proved the latter to be unreliable. Any wider application of drive census was not feasible because of high costs involved. Individuals in ungulate populations usually are cumulatively distributed. This requires expanding the sample area and to increase the number of samples to make the result credible (Caughley, 1977). The method which combines the advantages of tracking method and drive census called drived tracking (Bobek et al., 1984) in practice cannot be used in mountains because of unfavourable conditions like deep snow and the topographical features that limit the application of that method.

In forest ecosystems of our geographical zone some other methods like pellet count (Dzięciołowski, 1976) and air census (Erickson \& Siniff, 1963; Le Rosche \& Rausch, 1974) do not yield reliable figures of deer population density, so we decided to test the Langvatn method (1977) that interpretes the social structure of red deer population during rut season. This method is based on the behavior of rutting red deer stags, can be applied independently of ground configuration and because at that time of the year deer are much easier to watch a relatively small number of observers is required.

\section{STUDY AREA, METHOD}

Data were collected during September and October 1984 in four forest districts of Bieszczady Mountains: Komańcza, Cisna, Wetlina and StuFosiany. In these four districts the areas covered by a survey were respectively: $11050 ; 6382,5618$ and 6734 ha. Deer were observed at early morning and at evening to coincide with known peaks of animals' activity. The observations involved authors and also the members of game management service.

Observers recorded identification numbers of forest units covered by a survey i.e. remaining within earshot during their route, marking these where roaring stags were heard. At the same time any deer units (groups or single animals) sighted on the route were recorded. The notes included information about the number of roaring stags with harems, stags that not roared but led harems, single roaring stags, single stags that not roared and any other social units.

Population numbers were calculated according to Langvatn (1977) formula:

$$
N=B+(B \cdot H) b+B \cdot C+(B \cdot H) c+B \sum_{i=1}^{n} x_{i} \cdot y_{i}
$$


where: $B-$ number of roaring stags

$b$ - average number of roaring stags with harems relative to all roaring stags visually observed

$C$ - average number of adult stags that not roared relative to all roaring stags observed

$c$ - average number of adult stags that not roared leading harems relative to all stags observed

$\mathrm{H}$ - average size of harems (adult stags not included)

$x_{1}, x_{2} \ldots x_{n}$ - size of social units $(1,2 \ldots n)$ not included in $B, C$ and $H$

$y_{1}, y_{2} \ldots y_{n}$ - average observation frequency of $x_{1}, x_{2} \ldots x_{n}$ relative to all roaring stags observed

\section{RESULTS}

Altogether in four studied forest districts 468 roaring stags (heard and seen) and 81 adult stags leading harems were recorded. 151 social units including hinds, calves and stags two years old or younger were observed. Most of data have been obtained from Komańcza - 166 roaring stags, 17 stags that not roared and 58 social units. The least number of observations - only 72 roaring stags, 8 that not roared and 12 social units were recorded in Cisna. In that forest district the largest average harem size (4.4) animals was found, while the smallest average harem (3.1 animals) was in Stuposiany and Wetlina (Table 1). The most

Table 1

Field data of red deer census ready to apply Langvatn formula from four forest districts in the Bieszczady Mountains. S - solitary stags, SH - stags with harem.

\begin{tabular}{|c|c|c|c|c|c|c|c|}
\hline \multirow{2}{*}{$\begin{array}{l}\text { Forest } \\
\text { districts }\end{array}$} & \multirow{2}{*}{$\begin{array}{c}\text { Roaring } \\
\text { stags } \\
\text { (heared } \\
\text { and sighed) }\end{array}$} & \multirow{2}{*}{$\begin{array}{l}\text { Harem } \\
\text { size } \\
\text { without } \\
\text { stag }\end{array}$} & \multicolumn{4}{|c|}{ Stags observed } & \multirow{2}{*}{$\begin{array}{l}\text { Other } \\
\text { social } \\
\text { units }\end{array}$} \\
\hline & & & $\mathbf{S}$ & $\underset{\mathrm{SH}}{\text { roaring }}$ & $\mathrm{S}_{\mathrm{S}}^{\text {not }}$ & $\stackrel{\text { ing }}{\text { SH }}$ & \\
\hline Komańcza & 166 & 3.9 & 51 & 33 & 13 & 4 & 58 \\
\hline Stuposiany & 148 & 3.1 & 83 & 60 & 40 & 5 & 50 \\
\hline Wetlina & 82 & 3.1 & 39 & 27 & 7 & 4 & 31 \\
\hline Cisna & 72 & 4.4 & 9 & 25 & 3 & 5 & 12 \\
\hline Total $/ \overline{\mathrm{x}}$ & 468 & 3.6 & 182 & 145 & 63 & 18 & 151 \\
\hline
\end{tabular}

often observed harem size, occuring in about $30 \%$ of observations, consisted of 3 animals (excluding leading stag) which was a little below the average harem size for all four studied districts (3.6 animals) (Fig. 1).

The yielded estimates of the total numbers of red deer in studied areas in Komańcza, Cisna, Stuposiany and Wetlina at 597, 392, 498 and 
265 respectively. The highest density per 100 ha has been found in Stuposiany (7.4) and the lowest in Wetlina (4.7) (Table 2).

The determination of the activity peak of roaring stags was based on the average number of roaring stags heard per one hour. In 1984 it fell on the period between 1 to 4 of October (Fig. 2). The largest number of deer sighted per hour was observed between 2 to 4 of October (Fig. 3).

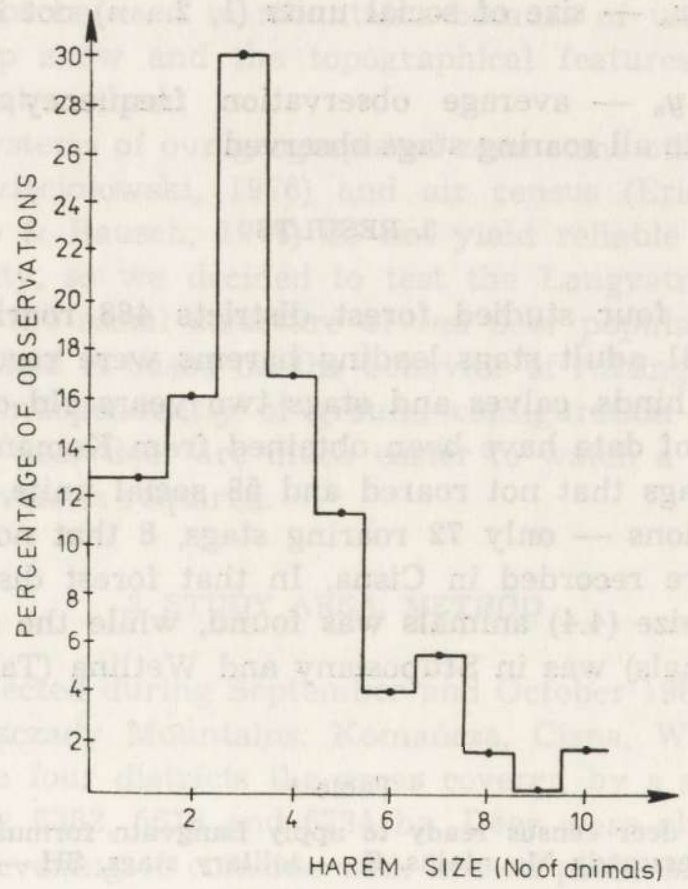

Fig. 1. The percentage of different harem sizes in the total number of observations of red deer groups in four studied forest districts in the Bieszczady Mountains during the rut season of 1984 .

Table 2

Estimations of red deer population density in four forest districts in the Bieszczady Mountains

\begin{tabular}{lcccc}
\hline & \multirow{2}{*}{$\begin{array}{c}\text { Area covered } \\
\text { by a survey } \\
\text { Forest district }\end{array}$} & \multicolumn{2}{c}{$\begin{array}{c}\text { Deer density (per 100 ha) } \\
\text { according to: }\end{array}$} \\
\cline { 4 - 5 } & & & Langvatn formula & official data \\
\hline Komańcza & 11050 & & 5.4 & 1.7 \\
Stuposiany & 6734 & 7.4 & 3.9 \\
Cisna & 6382 & 6.2 & 2.1 \\
Wetlina & 5618 & 4.7 & 0.9 \\
\hline
\end{tabular}




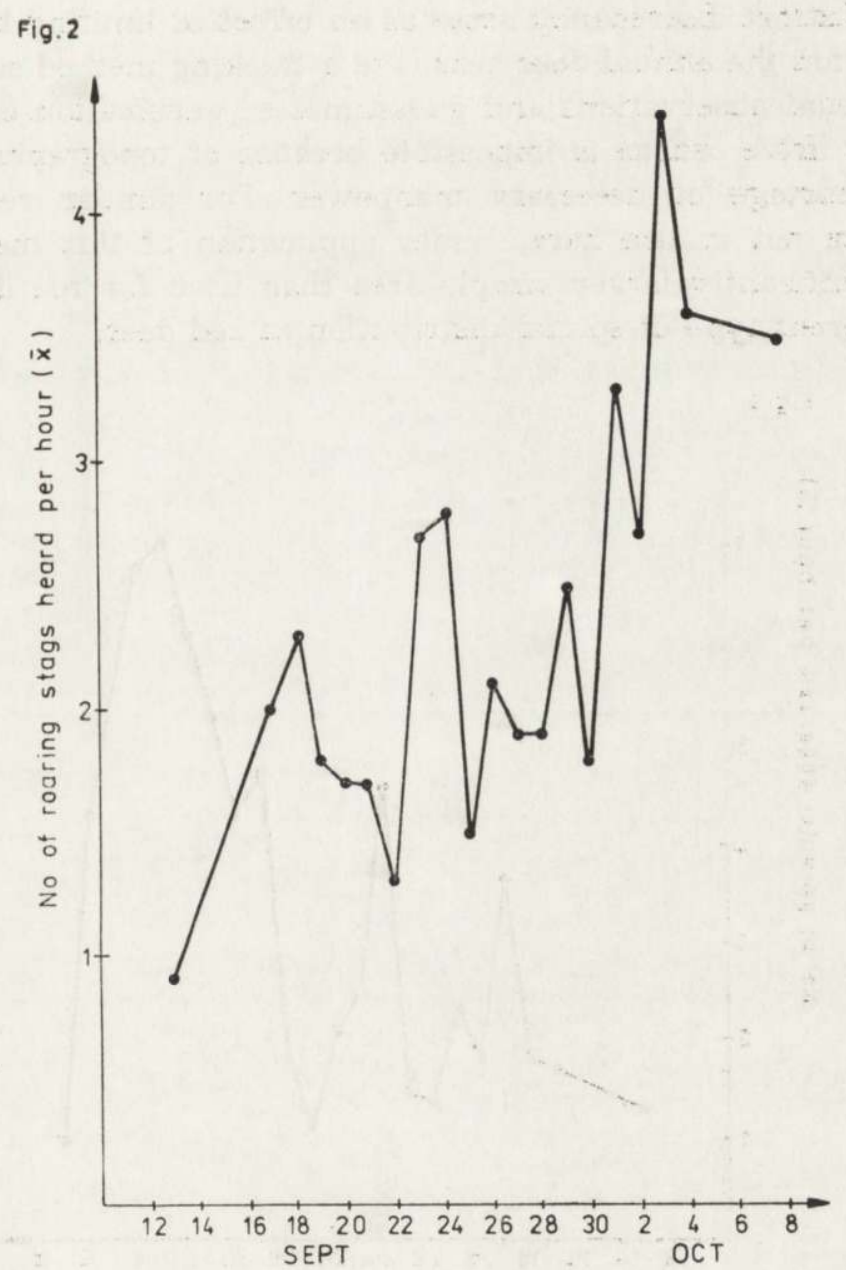

Fig. 2. The average number of roaring stags heard per hour in four studied forest districts in Bieszczady Mts. over the period between September 12 to October 8, 1984.

\section{DISCUSSION}

The official data concerning deer number in the Bieszczady Mountains are much lower than the estimations made according to Langvatn formula. On average the difference amounts to 3.5-4 animals per 100 ha (Table 2). In the same cases where the forest administration reported the exeptionaly low density of deer (like Wetlina and Komańcza) the population number calculated on the basis of the number of roaring stags exceeds the official data 4 to 5 times. 
Such a distinct discrepancy arose as an effect of limiting by the forest administration the annual deer census to a tracking method supplemented only by casual observations and guesstimates. Verification of these estimations by drive census is impossible because of topographical features and the shortage of necessary manpower. For similar reason drived tracking are not in use here. Wider application of this method would require significantly larger sample area than used for roe deer because of the different type of spatial distribution in red deer.

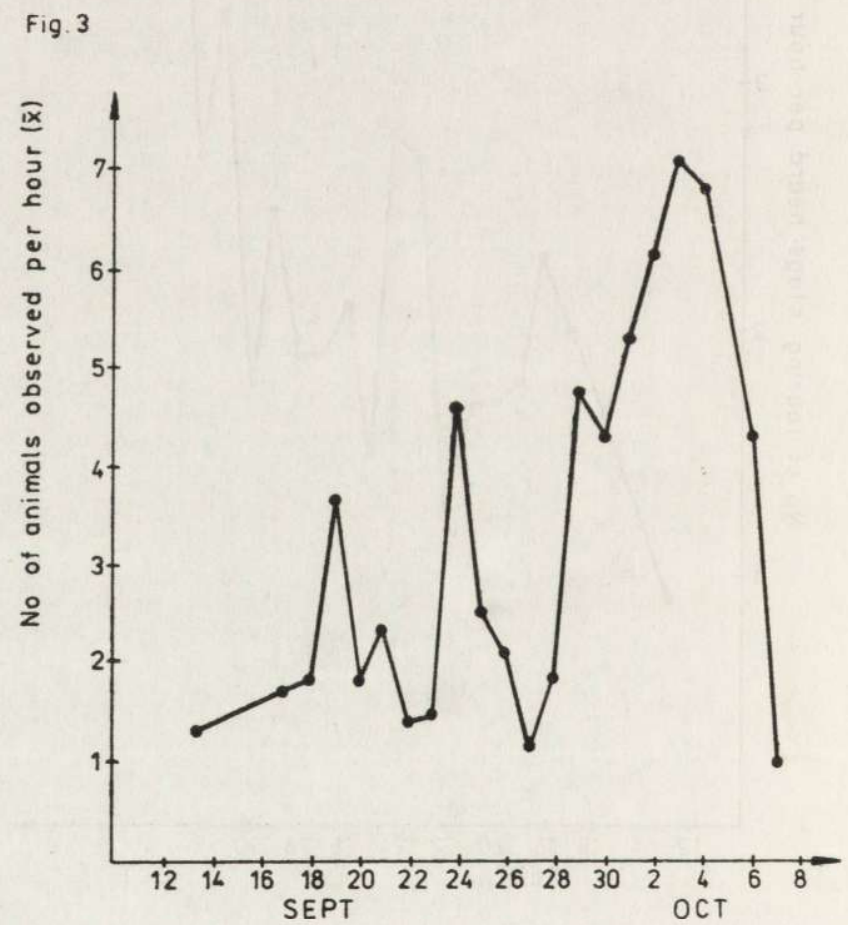

Fig. 3. The average number of red deer observed per hour in four studied forest districts in Bieszczady Mts. over the period between September 12 to October 8, 1984.

The results obtained by applying Langvatn formula are much higher than the official data nevertheless the results of both are highly positively correlated $(r=0.98)$. It implies that the proposed method accurately reflects existing trend of deer number. The level of accuracy of estimation based on that method is positively correlated to the number of roaring stags and to area covered by a survey. There are two possible explanations why Langvatn method gives higher figures. As it was already mentioned the traditional way of census i.e. snow tracking under- 
estimates several times the actual population number. The results are also seriously affected by the season of the year in which the census is carried out. Data collected during rut season include also these individuals which are harvested during hunting season like hinds and calves which are shoot off in late winter, or individuals which die from natural reasons during winter or fall prey to wolves (Okarma, 1984; Bobek \& Kosobucka, 1985).

The official census of deer population is usually carried out at the end of the winter when population number is at its lowest level. Hence the apparent differences between both these estimates become understandable and easy to explain. Thus the method of censusing red deer based on the number of roaring stags is worth of recomendation. Saving of manpower is the additional benefit of that method. Since the most intensive period of hunting season falls on the time of red deer rut, the foresters involved in game management are almost constantly present in the forest. They are accompanied at that time by many highly qualified hunters, licensed to selective harvesting of deer males. This situation provides an excellent opportunity to collect a lot of data on population structure and the number of roaring stags in the area without any extra effort and additional costs. The method also makes deer census in winter season unnecessary. Having the population number at rut, one can easily calculate the number of deer at the end of the winter substracting harvest and winter mortality. In addition the method provides estimates of male/female ratio and recruitment rate.

Obviously there are some limitations to the use of that method. The census should be performed on possibly large area (in range of thousands hectares) as by most of the year stag and hind units stay separately (Watson \& Stains, 1978; Van Georgii, 1980; Clutton-Brock et al., 1982). It is also possible that the administrative border between two hunting grounds would divide home ranges of males and females. In such a case one of these grounds would have excess or deficiency of deer regarding to previous estimation.

To obtain an evidence for results can be difficult when only the small percentage of stags in a population roars during the rut, however, the Langvatn formula to some extend compensates that shortcoming. Nevertheless, the higher percentage of roaring stags the more exact the final result.

These minor inconveniences not withstanding the method deserves wider appreciation and its inclusion into standard practice should be seriously taken under consideration. This would help to set the records straight and give long awaited and much needed more accurate estimates of deer population numbers in Poland. 


\section{REFERENCES}

1. Bobek B, \& Kosobucka M., 1985: Modelling of the population dynamies and structure in red deer (Cervus elaphus) in southeastern Poland. Proc. XVIIth Congr, of Int. Union of Game Biol.. 173-181. Brussels.

2. Bobek B., Morow K. \& Perzanowski K., 1984: Ekologiczne podstawy gospodarki łowieckiej. PWRiL. Warszawa. $314 \mathrm{pp}$.

3. Bobek B. \& Tomek A., 1973: Uwagi o liczeniu zwierzyny. Łowiec pol., 8: $2-3$.

4. Clutton-Brock T. H., Guinnes F. E. \& Albon S. D., 1982: Red deer: behaviour and ecology of two sexes. Univ. Chicago Press, Chicago $378 \mathrm{pp}$.

5. Caughley G., 1977: Analysis of vertebrate populations. J. Wiley and Sons. London. $234 \mathrm{pp}$.

6. Dzięciołowski R., 1976: Roe deer census by pellet-group counts. Acta theriol., 21: $351-358$.

7. Erickson A. W. \& Siniff D. B., 1963: A statistical evaluation of factors influencing aerial survey results. North Amer. Wildl. Conf., 28: 391-408.

8. Langvatn R., 1977: Social behavior and population structure as a basis for censusing red deer population. Proc. XIIIth Congr. Game Biol.: 77-89. Atlanta.

9. Le Rosche R. E. \& Rausch R. A., 1974: Accuracy and precision of aerial moose counting. J. Wildl. Manage., 38: 175-182.

10. Miłkowski L., 1969: Z doświadczeń nad inwentaryzacją zwierzyny w Puszczy Białowieskiej. Łowiec pol., 22: 4-5.

11. Okarma H., 1984: The physical condition of red deer falling a prey to the wolf and lynx and harvested in the Carpatian Mountains. Acta theriol., 29: 283-290.

12. Pucek Z., Bobek B., Łabudzki L., Miłkowski L., Morow K. \& Tomek A. 1975: Estimates of density and number of ungulates. Pol. Ecol. Stud., 1: 121-136.

13. Van Georgii B., 1980: Home range patterns of female red deer (Cervus elaphus L.) in the Alps. Oecologia, 47: 278-285.

14. Watson A. \& Staines B. W., 1978: Differences in the quality of wintering areas used by male and female red deer (Cervus elaphus L.) in Aberdeenshire. J. Zool., 286: $544-550$.

Accepted, April 3, 1986.

Bogusław BOBEK, Kajetan PERZANOWSKI i Jan ZIELIŃSKI

OCENA LICZEBNOSCI POPULACJI JELENIA W GORACH: TESTOWANIE ALTERNATYWNEJ METODY

Streszczenie

Liczebność populacji jelenia szlachetnego Cervus elaphus (Linnaeus, 1758) została oceniona $w$ caterech nadleśnictwach bieszczadzkich na podstawie struktury socjalnej tej populacji oraz liczby ryczących byków zgodnie z równaniem Langvatn (1977). Oba parametry charakteryzujące aktywność jeleni — średnia liczba 
ryczących byków słyszanych w ciągu godziny oraz średnia liczba jeleni obserwowanych w ciągu godziny osiągnęly najwyższe swe wartości 3 października. Szczyt aktywności związanej $\mathrm{z}$ rykowiskiem przypadł więc na okres pomiędzy $2-4$ października (Ryc. 2, 3). Srednia wielkość haremu wynosiła 3,6 osobników, podczas gdy najczęściej spotykanym był harem złożony z trzech zwierząt ( $30 \%$ wszystkich obserwacji) (Ryc. 1, Tabela 1).

Zagęszczenie populacji jelenia wynosiło odpowiednio w Stuposianach, Cisnej, Komańczy i Wetlinie: 7,4; 6,2; 5,4 i 4,7 osobników na 100 ha. Wartości te uzyskane na początku sezonu łowieckiego przewyższają oficjalne dane uzyskiwane poprzez tropienia na śniegu (zazwyczaj pod koniec sezonu) o okolo 2-5 razy (Tabela 2). Metoda oceny liczebności oparta na równaniu Langvatn okazała się szczególnie przydatną dla łowisk górskich, będąc tutaj tańszą i dającą wyniki bardziej realistyczne niż dotychczas stosowane rutynowo szacowanie liczebności oparte na tropieniach i dorywczych obserwacjach. 